УДК 81.161.1'373

\title{
ПРОБЛЕМА ИЛЛЮСТРИРОВАНИЯ ЦЕРКОВНОЙ ЛЕКСИКИ В СОВЕТСКИХ ТОЛКОВЫХ СЛОВАРЯХ
}

Богданчикова Татьяна Юрьевна студент

\author{
Научный руководитель: Смирнова Светлана Анатольевна \\ к.ф.н., доцент \\ Гуманитарный институт ФГАОУ ВО «Северного (Арктического) \\ федерального университета имени М.В. Ломоносова»
}

\begin{abstract}
Аннотация: в статье рассматриваются особенности иллюстрирования лексем тематической группы «Наименования церковных помещений и их частей» в толковых словарях, делаются выводы об изменении объема и содержания соответствующей зоны. Материалом исследования являются статьи лексикографических изданий советского и постсоветского периодов. В результате сравнительного анализа формулируются способы отбора цитат и речений для иллюстративной зоны разделов, где характеризуется церковная лексика, выявляются особенности практики словарного дела периода СССР.

Ключевые слова: церковная лексика, лексикографический аспект, толковый словарь, словарная статья, иллюстративная зона.

\section{THE PROBLEM OF ILLUSTRATING CHURCH VOCABULARY IN SOVIET EXPLANATORY DICTIONARIES}

\section{Bogdanchikova Tatyana Yurievna Scientific adviser: Smirnova Svetlana Anatolievna}

\begin{abstract}
: the article analyzes the peculiarities of illustrating the lexemes of the thematic group "Church premises and their parts" in explanatory dictionaries, and draws conclusions about quantitative and qualitative changes. The material of the research is dictionary articles from Russian Explanatory Dictionaries of the Soviet and post-Soviet periods. As a result of the comparative analysis, the methods of selecting quotations and utterances for the illustrative zone of the articles where the church vocabulary is characterized are formulated, and the peculiarities of the vocabulary practice of the USSR period are revealed.
\end{abstract}


Key words: church vocabulary, lexicographic aspect, explanatory dictionary, dictionary article, illustrative zone.

В советском государстве религиозно-церковная лексика стала жертвой идеологических гонений: она отражала «устаревшее» мировоззрение, которое необходимо было искоренить для формирования «нового человека». В настоящее время данные единицы возвращаются в разговорное употребление: этому во многом способствуют СМИ, которые обращаются к лексемам сферы «Церковь» для «большей эмоциональности, экспрессивности» информационных продуктов [1]. Рассматриваемая группа слов после нескольких десятилетий «забвения» вновь фигурирует в речи, а значит, становится предметом пристального внимания русистов, в том числе с точки зрения описания в толковых словарях. Эта лексика определенным образом фиксировалась в изданиях советского периода, хотя и была в них одной их самых малочисленных групп [2]; целью могла быть демонстрация отсталости «отжившего, дореволюционного строя и верующих людей» [3], а также представление негативной оценки христианского мировоззрения. Кроме того, у данных лексем появлялись новые значения, не связанные с духовной сферой, которые уже без сомнений должны были быть отражены в словниках. Подбор примеров речевого употребления к «светским» значениям не вызывал существенных затруднений у авторов; иллюстрирование первоначальных толкований порождало вопросы. В настоящей статье анализируются имена существительные алтарь, иконостас, храм, иерковь; задача статьи - путем сравнения выявить способы отбора цитат и речений для соответствующей зоны статьи в толковых словарях советского периода. В качестве источника материала выступают следующие лексикографические труды разной хронологии: «Толковый словарь русского языка» под ред. Д.Н. Ушакова (далее - ТСУ), «Словарь русского языка» А.П. Евгеньевой (далее - МАС), «Толковый словарь русского языка» С.И. Ожегова и Н.Ю. Шведовой (далее - ТСОШ), «Большой толковый словарь русского языка» С.А. Кузнецова (далее - БТС).

В рассматриваемых изданиях имя алтарь описывается как многозначное: (1) 'жертвенник': потух огонь на алтаре (А.С. Пушкин); (2) 'главная часть церкви': в иллюстративной зоне цитат и речений нет; дополнительно характеризуется значение с пометами перен., книжн., поэт., устар. 'церковь, религия': он сердием почитать привык алтарь (А.С. Пушкин), приводится устойчивое сочетание «возложить или принести на алтарь» с пометами книжн., 
pumop., nоэт., ycmap. - 'принести что-нибудь в жертву чему-нибудь': на алтарь отечества. На алтарь искусства [4, с. 39]; (1) 'место для жертвоприношений у первобытных народов; жертвенник': в иллюстративной зоне цитат и речений нет; (2) 'восточная часть церкви, где находится престол, отделенная от общего помещения иконостасом': [cмотритель] поспешно вошел в цуерковь: священник выходил из алтаря; дьячок гасил свечи, две старушки молились ещуе в углу (А.С. Пушкин); приводится сочетание «возложить (или принести) на алтарь отечества (или искусства, науки, любви и т.п.)» с пометой высок. - 'пожертвовать чем-либо во имя отечества, искусства и т.П.' [5]; (1) 'восточная возвышенная часть христианского храма (в православной церкви отделённая от общего помещения иконостасом)': в иллюстративной зоне цитат и речений нет; (2) ‘в старину: то же, что жертвенник': в иллюстративной зоне цитат и речений нет; описывается сочетание «принести свою жизнь на алтарь отечества» с пометами перен., высок. - 'пожертвовать своей жизнью во имя родины', приводится дериват алтарный [6]; (1) 'место для жертвоприношений у языческих народов; жертвенник': в иллюстративной зоне цитат и речений нет; (2) 'часть храма, в которой на возвышении находится святой престол': в иллюстративной зоне цитат и речений нет; (3) с пометой высок. 'о месте, внушающем благоговение': сиена в театре - это алтарь искусства; описываются сочетания «вести к алтарю» с пометой высок. - 'жениться; венчаться', «возложить (принести) что-либо на алтарь отечества (искусства, науки, любви и т.п.)» с пометой высок. - 'пожертвовать чем-либо во имя отечества, искусства и т.П.’. Приводится дериват алтарный [7].

Сравнительный анализ показывает: объем и содержание иллюстративной зоны претерпевают определенные изменения. Прямые значения, непосредственно связанные с религией ('часть церкви'), не иллюстрируются в ТСУ, ТСОШ и БТС. В МАС у конфессионального толкования цитируется А.С. Пушкин, «Станционный смотритель». Дефиниции, не имеющие отсылок к христианским культовым сооружениям, иллюстрируются лишь в ТСУ (А.С. Пушкин) и БТС (анонимное речение). В трудах советского периода фиксируется выражение «возложить/принести на алтарь (отечества и т.п.)»; на наш взгляд, оно содержит явно выделяющийся идеологический компонент - в СССР призывы подобной направленности не сходили с повестки дня. Эта своего рода идиома сохраняется в ТСОШ и БТС. В БТС примечательно сочетание «вести к алтарю», свидетельствующее о вновь появившемся в обществе интересе к церковным обрядам. 
Выявлены следующие толкования лексемы иконостас: 'в православной церкви - уставленная иконами стена, отделяющая алтарь от основной части': в иллюстративной зоне цитат и речений нет [4, с. 465]; 'легкая стена с вставленными в нее иконами, отделяющая в православной церкви алтарь': в иллюстративной зоне цитат и речений нет [5]; 'покрытая иконами стена, отделяющая алтарь в православном храме': в иллюстративной зоне цитат и речений нет; приводится дериват иконостасный [6]; (1) 'в православной церкви: стена с иконами, отделяющая алтарь': реставращия иконостаса; (2) с пометой шутл. 'о большом количестве орденов, медалей, значков, навешанных на чью-либо грудь': нацепить на грудь иконостас [7].

Прослеживаются изменения в объеме и содержании иллюстративной зоны: в трех из представленных изданий у единицы описывается только одно значение - прямое; какие-либо цитаты и речения при нем отсутствуют. На наш взгляд, это может быть обусловлено тем, что именно такую сакральную лексику негласно предписывалось как можно скорее перевести в разряд «устарелой», чтобы в буквальном смысле вытравить ее из сознания людей; в этом случае иллюстративная зона оставлялась пустой намеренно. В БТС ситуация изменилась: показательно речение реставрация иконостаса, документально подтверждающее характерное явление конца XX века. Лексема также проникает в разговорный дискурс, приобретая значение с шутливой мелиоративной коннотацией, которое сопровождается иллюстративным материалом.

В рассматриваемых трудах имя храм описывается как многозначное: (1) с пометами книжн., церк. 'здание для богослужения, церковь': в иллюстративной зоне цитат и речений нет; (2) с пометами перен., pитор. 'место, предназначенное для занятий чем-н.': храм науки. Храм искусства [8, с. 560]; (1) 'здание, предназначенное для совершения богослужений и религиозных обрядов’: буддийский храм. Над вершинами леса, на фоне темно-зеленой хвои и голубого небосклона, ярко выделяются купола храмов, сияя золотистыми крестами (А.С. Новиков-Прибой). Около мыса Фиолент мы долго искали развалины храма Дианы, но ничего не нашли (К.Г. Паустовский); (2) с пометами перен., высок. 'место, внушающее по каким-либо причинам чувство глубокого почтения, благоговения': из пансиона скоро вышел он, Наскуча все твердить азы да буки, И, наконеи, в студенты посвящен, Вступил надменно в светльй храм науки (М.Ю. Лермонтов). Если в театре художественно даются художественные произведения, то театр - храм муз, источник высоких 
душевных наслаждений (А.Н. Островский); (3) 'область, сфера каких-либо высоких духовных ценностей’: с юга пешком привела его страсть $B$ дальнюю нашу столииу - Думал бедняга в храм славы попасть - Рад, что попал и в больнииу! (Н.А. Некрасов). [Вагин:] Mы дружно служим в светлом храме Свободы, правды, красоты (М. Горький) [5]; (1) 'здание для богослужения, церковь': древнерусские храмы. Буддийский храм; (2) с пометами перен., высок. 'место служения науке, искусству, высоким помыслам': храм науки; описывается устойчивое сочетание с пометой высок. «дорога к храму» - 'путь к вере, к Богу'; приводятся дериваты храмный и храмовой; описываются словосочетания «храмовой праздник» - 'праздник в честь какого-нибудь события или святого, именем которого назван храм' и «храмовая икона» 'икона с изображением лика святого, именем которого назван храм' [6]; (1) 'здание, предназначенное для совершения богослужений и религиозных обрядов': древнерусские храмы. Храмы Московского Кремля. Буддийский храм. Храм богини Дианы; приводится сочетание «дорога к храму» - 'о возвращении к религиозным духовным ценностям'; (2) с пометой высок. 'о чём-либо, внушающем чувство глубокого почтения, благоговения': храм науки. Храм муз. Природа - тот же храм (О.Э. Мандельштам); приводятся дериваты храмовой, храмовый: храмовая ограда. Храмовые купола, стены. Храмовый праздник ('праздник в честь какого-либо события или святого, именем которого назван данный храм’) [7].

Сравнительный анализ позволяет утверждать, что объем и содержание иллюстративной зоны изменяются. Прямые значения, связанные с культурой православия, сопровождаются цитатами и речениями во всех изданиях, кроме ТСУ. В МАС иллюстративные зоны трех зафиксированных толкований необычайно насыщены примерами употребления единицы. Речение, которое сопровождает первое, связанное с религией значение, на наш взгляд, сознательно подобрано авторами так, чтобы ослабить представление пользователя словаря о храме как о христианском культовом сооружении - он не православный и даже не католический, а буддийский; «развалины храма Дианы» - руины римской постройки. Исключением становится цитата из рассказа «Судьба» А.С. Новикова-Прибоя: описано явно православное сакральное место. Но и здесь можно обнаружить замаскированный идеологический компонент: у подготовленного читателя, знакомого с указанным произведением, в котором главный герой отрекается от навязываемого матерью монашеского пути в пользу морской службы, эта 
цитата актуализировала бы представление о религии как об «опиуме (для) народа». Вторая дефиниция с пометами перен., высок. иллюстрируется отрывками из творений признанных классиков М.Ю. Лермонтова и А.Н. Островского; третья - цитатами Н.А. Некрасова и М. Горького. В ТСОШ конфессиональное толкование сопровождают речения, в определенной степени подобранные более корректно: храмы уже не только буддийские, но и древнерусские. Примечательно сочетание «дорога к храму» с пометой высок. в значении 'путь к вере, Богу': оно внесено в словарь, вероятно, в связи с прекращением травли исповедующих православие. В БТС значение этого же выражения - 'о возвращении к религиозным духовным ценностям' - еще точнее отражает характерные общественные настроения. Сочетания «храмовой праздник», «храмовая икона» в ТСОШ и БТС снабжают читателя сведениями энциклопедического характера. В БТС в целом наблюдается значительная деидеологизация толкований рассматриваемой лексемы, на что указывает речение храмы Московского Кремля у прямого значения; а также цитата О.Э. Мандельштама у переносного. Появление этого имени и словосочетания в сочинении, по нашему мнению, стало возможным именно после распада СССР и значительного ослабления идеологического гнета.

У лексемы цзерковь выявлены следующие толкования: (1) 'здание, в котором происходит богослужение': каменная церковь. Деревянная церковь. Пятиглавая цеековь. Шатровая цеерковь. Отвести церковь под клуб; (2) 'христианская организация, объединенная единством догматов и обрядов': православная цүерковь. Католическая цеерковь. Лютеранская церковь. Господствуюшая цеерковь. Отизы цүеркви. Живая цүерковь; (3) 'руководство такой организации': решение церкви [8, с. 574]; (1) 'религиозная организация духовенства и верующих, объединенная общностью верований и обрядности': православная церковь. Католическая цүерковь. Отделение цуеркви от государства; (2) 'здание, в котором происходит христианское богослужение. Белокаменная церковь': собралось такое множество почетных богомольиев, что простые крестьяне не могли поместиться в цуеркви и стояли на паперти и в ограде (А.С. Пушкин). Белая деревянная церковь, с зелеными куполами $и$ золотылми крестами, стояла на горе (А.С. Новиков-Прибой) [5]; (1) 'объединение последователей той или иной религии, организация, ведающая религиозной жизнью и соответствующим культом; религиозная община' православная церковь. Католическая церковь. Протестантские церкви (например, лютеранская, англиканская); (2) 'православный храм': каменная 
церковь. Церковь с колокольней. Ходить в иерковь. Приводится сочетание «соборная церковь» - 'то же, что церковный собор', уменьшительноласкательные формы це́рковка, церко́вка и церквушка ко второму значению, дериват иерковный: иерковная литература. Церковная музыка. Церковная служба. Церковный брак. Церковные праздники. Церковные действа (обряды русской православной церкви). Церковная паперть. Характеризуется сочетание «церковный собор»: 'съезд высшего духовенства христианской церкви для решения вопросов вероучения, церковного управления' [6]; (1) 'религиозная организация духовенства и верующих, объединённая общностью верований и обрядности; религия, проповедуемая такой организацией': православная церковь. Католическая церковь. Отць иеркви (толкователи христианского вероучения); (2) 'здание, в котором происходит христианское богослужение': белокаменная церковь. Деревянная церковь. Трёхглавая церковь. Венчаться, отпевать кого-либо в церкви. Ходить в иерковь (быть верующим). Евангелическая иерковь. Баптистская иерковь. Лютеранская иерковь. Приводятся уменьшительно-ласкательные формы церквушка, иерковка ко второму значению [7].

Дефиниции с ключевым компонентом 'здание, в котором происходит богослужение' во всех используемых словарях сопровождаются цитатами и речениями; но в каждом сочинении этот материал имеет свои особенности. Так, в ТСУ рассматриваемое толкование иллюстрируют речения, среди которых показательно отвести церковь под клуб, являющееся документальным подтверждением действий, осуществлявшихся в СССР в рамках антирелигиозной кампании. Сочетание, иллюстрирующее второе значение (Живая церковь) является отчетливым маркером эпохи: такое название носила организация, просуществовавшая с 1922 по 1936 год и скомпрометировавшая себя тесным сотрудничеством с советской властью, многочисленными доносами. В МАС лексема церковь в значении 'организация' сопровождается несколькими речениями; в значении 'здание' - речением и цитатами из произведений А.С. Пушкина и А.С. Новикова-Прибоя. Сочетание отделение церкви от государства у первого толкования явно отсылает читателя к соответствующему Декрету 1918 года; другие содержат сведения энциклопедического характера (cp. православная иерковь, католическая церковь и др.). В ТСОШ к подобному материалу добавляются сочетания соборная церковь, церковный собор. Речения, содержащие названия православных обрядов, на наш взгляд, свидетельствуют о возвращении этих 
номинаций в разговорный дискурс в связи со снятием запрета на проведение сакральных действ. В БТС рядом с идентичными речениями присутствует показательное ходить в церковь в значении 'быть верующим': в общественном сознании легитимируется возможность исповедать христианство.

Итогом предпринятого исследования стали установленные нами способы отбора материала для иллюстративной зоны статей, описывающих церковную лексику, к которым прибегали в лексикографической практике в период СССР.

1. Эту зону статей рассматриваемых единиц оставляли пустой, не включая в нее цитаты и речения (см. алтарь в ТСУ, иконостас в ТСУ и МАС, храм в ТСУ), демонстрируя подобным образом отсутствие примеров речевого употребления. Вероятнее всего, этот принцип частично перешел в ТСОШ и БТС «по наследству». Отметим, что процесс деидеологизации словарей продолжается до сих пор.

2. В зону иллюстрации включали цитаты из произведений либо общепризнанных классиков, либо советских писателей (см. алтарь в ТСУ, храм и цеерковь в МАС). Такой материал подчеркивал несовременность церковной лексики; во втором случае он дополнял толкования, составленные с учетом идеологических предписаний.

3. В иллюстративную зону помещали речения, демонстрирующие негативное отношение к православию, а также отражающие определенные общественные процессы (см. церковь в ТСУ). Кроме того, они являли собой допустимые примеры речевого употребления единиц (см. алтарь в ТСУ и MAC). Такие сочетания, не содержащие явного идеологического компонента, перешли «по наследству» в словари постсоветского времени.

\section{Список литературы}

1. Прядко И.П. Церковная лексика в практике современных СМИ / И.П. Прядко. - [Электронный ресурс] - Режим доступа: http:/gramota.ru/biblio/magazines/gramota/kultura/28_65 (дата обращения: 11.02.2021).

2. Емельянова О.Н. Церковная лексика в Малом академическом словаре русского языка / О.Н. Емельянова // Вестник Красноярского государственного университета. Гуманитарные науки. - 2000. - № 2. - С. 101-104.

3. Крылова И.А. Проблемы описания лексики сферы религии в толковых словарях русского языка / И.А. Крылова // Studia Humanitatis. - 2020. - № 4. 12 c. - [Электронный pecypc] - Режим доступа: https://cyberleninka.ru/article/n/problemy-opisaniya-leksiki-sfery-religii-v-tolkovyh-slovaryah-russkogo-yazyka (Дата обращения: 19.02.2021). 
4. Толковый словарь русского языка: в 3-х т. Т. 1. А - М / под ред. проф. Д.Н. Ушакова. - М.: Вече, Мир книги, 2001. - 704 с.

5. Словарь русского языка: в 4-х т. / под ред. А.П. Евгеньевой. - 2-е изд., испр. и доп. - М.: Русский язык, 1981 - 1984. - [Электронный ресурс] - Режим доступа: http://slovari.ru/default.aspx?s=0\&p=240 (Дата обращения: 20.03.2021).

6. Толковый словарь русского языка / С.И. Ожегов, Н.Ю. Шведова. - М.: Азъ, 1992. - [Электронный ресурс] - Режим доступа: http://slovari.ru/default.aspx?s=0\&p=244 (Дата обращения: 20.03.2021).

7. Большой толковый словарь русского языка / гл. ред. С.А. Кузнецов. СПб.: Норинт, 1998. - [Электронный ресурс] - Режим доступа: http://gramota.ru/slovari/info/bts/ (Дата обращения: 16.03.2021).

8. Толковый словарь русского языка: в 3-х т. Т. 3. Р - Я / под ред. проф. Д.Н. Ушакова. - М.: Вече, Мир книги, 2001. - 672 с.

() Т.Ю. Богданчикова, 2021 